\title{
Issues in countries of the former Soviet Union as the driving force for female migration to Turkey
}

\author{
Dr. Oksana Koshulko, Ph.D. ${ }^{1, a^{*}}$, Dr. Guncel Onkal, PhD. ${ }^{2, b}$ \\ ${ }^{1}$ Scholar of TUBITAK, Ph.D. in Economic Sciences, Associate Professor, Postdoctoral Researcher, \\ Maltepe University, Istanbul, Turkey \\ ${ }^{2}$ Associate Professor, Chair of the Department of Sociology (Eng.), Vice-Dean, Maltepe University, \\ Istanbul, Turkey \\ E-mail address: aoksanakoshulko2015@gmail.com, bguncelo@gmail.com
}

Keywords: Turkey; countries of the former Soviet Union; minimum wage; GDP per capita; female migration

\begin{abstract}
The article presents the results and conclusions of a postdoctoral research project entitled "The migration of women from former Soviet Union countries to Turkey: differences, similarities, and outcomes" that has been conducted in Turkey among women from countries of the former Soviet Union with the aim of exploring the issues in these countries as the driving force for female migration to Turkey and also the causes, problems, difficulties, opportunities, prospects, achievements and outcomes of female migrants in the host country. The basis of this scientific project was semi-structured interviews and focus groups among women from former Soviet Union countries in Turkey.
\end{abstract}

\section{INTRODUCTION}

Economic, political crises, wars, revolutions, unemployment, poverty, low wages and pensions in countries of the former Soviet Union force women from these countries to look for better prospects in Turkey. Did they receive everything what they wanted in this host country or not, when they came to Turkey? Of course, key issues for these women when they plan to go to Turkey are their desires and expectations in the host country and also their level of education, culture and moral principles in general. If women plan to go to Turkey without knowledge of the Turkish language and Laws, without any official contracts for jobs and without any support from anybody in the host country, almost certainly they will face problems of violence, discrimination, sexual harassment, abuse, slavery, prostitution etc. If women plan to marry Turkish men, they will face challenges relating to religion, education, culture and social status of the family they will join. So, our goals were to explore the most common problems for women from countries of the former Soviet Union in the host country.

\section{THE FRAMEWORK OF THE SCIENTIFIC PROJECT}

In the framework of this scientific project we met hundreds of women from almost all countries of the former Soviet Union, except women from Tajikistan. We held semi-structured interviews with them and also focus-groups. We spoke with women with differing levels of education and culture and with different social statuses due to statuses according to the status of their husbands in Turkey, but there is one thing that unites them, - the fear and the uncertainty about their future in the host country.

\section{DATA AND METHODOLOGY}

In this article we used primary statistical data collected from interviews with female migrants from countries of the former Soviet Union in Turkey, using methodology in our research that consisted of qualitative research methods (field research; participant observations; semi-structured interviews; and focus group interviews), and also methods of economic analysis with the goal of 
analyzing and explaining the phenomenon of female migration from countries of the former Soviet Union in Turkey.

\section{HOW DID THE MIGRATION OF WOMEN TO TURKEY FROM COUNTRIES THE FORMER SOVIET UNION START?}

After the fall of the "Iron Curtain" in the Soviet Union many women from former Soviet Union countries started exploring new opportunities for living abroad. Many women, who came to Turkey twenty or more years ago, were without knowledge of the Turkish language and without any rights to work officially in the host country, and they began to work as prostitutes. Because of this the host country still remembers the phenomenon of 'Natasha'.

Some of these first women from former Soviet Union countries were deported from Turkey, some became as wives of Turkish men, and some of them found better opportunities for life in other countries, but the reputation of 'Natasha' is still alive in Turkey, and this phenomenon adversely affects the lives of next generation of women from former Soviet Union countries in the host country.

\section{WHY DID THE MIGRATION OF WOMEN TO TURKEY FROM COUNTRIES OF FORMER SOVIET UNION START?}

The migration of women from former Soviet Union countries to Turkey started because of very big economic problems in the countries of origin of these women. The analysis of minimum wages in Turkey and former Soviet Union countries can show and confirm this.

A minimum wage is the lowest daily or monthly remuneration that employers may legally pay to workers. Equivalently, it is the lowest wage at which workers may sell their labor. Although minimum wage laws are in effect in many jurisdictions, differences of opinion exist about the benefits and drawbacks of a minimum wage [1]. Supporters of the minimum wage say it increases the standard of living of workers, reduces poverty, reduces inequality, and boosts morale and forces businesses to be more efficient [2].

The majority of former Soviet Union countries in 2014 had lower minimum wages than Turkey (Fig. 1).

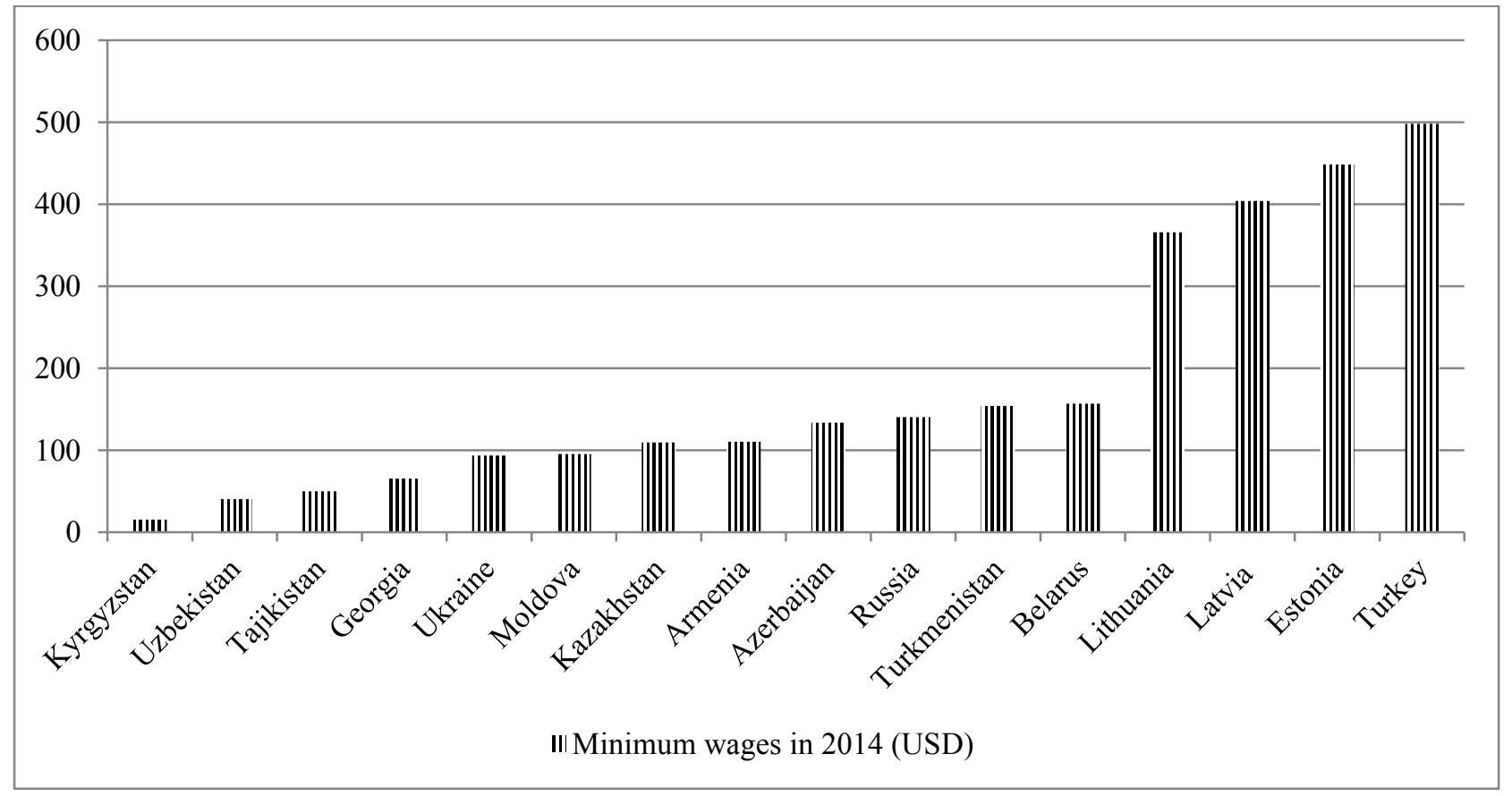

Fig. 1 - Minimum wages in former Soviet Union countries and Turkey in 2014 (USD) [3] 
In 2014 in Turkey the minimum wage was 1134 Turkish lira (TL) per month or approximately 497.8 USD [3]. At the same time the minimum wage

in Armenia was 45,000 Armenian dram (AMD) per month or 110.41 USD;

in Azerbaijan it was 105 Azerbaijani manta (AZN) per month or 133.86 USD;

in Belarus it was 1,660,000 Belarusian rubles (BYR) per month or 156.75 USD;

in Estonia it was $€ 355$ per month or 448.45882 USD;

in Georgia it was 115 Georgian lari (GEL) per month for public employees or 65.61 USD;

in Kazakhstan it was 19,966 Kazakhstani tenge (Kazakh tenge) per month or 109.753102 USD;

in Kyrgyzstan it was 840 Kyrgyzstani som (KGS) per month or 15.44 USD;

in Latvia it was €320 per month or 404.25600 USD;

in Lithuania it was 1000 Lithuanian litas per month or 365.82500 USD;

in Moldova it was 1400 Moldovan lei in the private sector or 95.66200 USD and 900 Moldovan lei per month in the public sector or 61.49700 USD;

in Russia it was 5,554 rubles per month or 140.371796 USD;

in Tajikistan it was 250 Tajikistani somoni per month or 50.02 USD;

in Turkmenistan it was 440 Turkmenistani manta (TMT) per month or 154.37 USD;

in Ukraine it was 1218 Ukrainian hryvna (UAH) per month or 93.98 USD;

in Uzbekistan it was 96,105 Uzbekistani som per month or 40.55631 USD.

Using this data Fig. 1 shows the list of former Soviet Union countries and Turkey, ranked by minimum wages of these countries in 2014 (USD).

Based on the data in Fig. 1, the lowest minimum wage in 2014 among countries of former Soviet Union was in Kyrgyzstan, where it was only 15.44 USD per month, and the highest was in Estonia at $€ 355$ per month or approximately 448.46 USD.

The highest minimum wages in 2014 among countries of the former Soviet Union were in Estonia, Latvia, and Lithuania (Table 1).

Table 1 - The comparison of minimum wages in 2014 in Estonia, Latvia, Lithuania, and Turkey

\begin{tabular}{|l|l|l|l|}
\hline Countries & $\begin{array}{l}\text { Minimum wages in 2014 in } \\
\text { Estonia, Latvia, Lithuania, and } \\
\text { Turkey (USD) }\end{array}$ & $\begin{array}{l}\text { The differences in minimum wages } \\
\text { of Turkey and these three countries } \\
\text { (USD) }\end{array}$ & $\%$ \\
\hline Turkey & 497.86 & & 9,92 \\
\hline Estonia & 448.45 & 49,41 & 18,80 \\
\hline Latvia & 404.25 & 93,61 & 26,52 \\
\hline Lithuania & 365.82 & 132,04 & \\
\hline
\end{tabular}

The differences in minimum wages of Turkey and Estonia, Latvia, Lithuania are not so big because currently the last three countries are members of the European Union.

Table 2 compares, analyses and ranks the minimum wages in Turkey, Belarus, Turkmenistan, Russia, Azerbaijan, Armenia, and Kazakhstan in 2014 in USD.

Table 2 - The comparison of differences in minimum wages in Turkey, Belarus, Turkmenistan, Russia, Azerbaijan, Armenia, and Kazakhstan in 2014 in USD

\begin{tabular}{|l|l|l|l|}
\hline Countries & $\begin{array}{l}\text { Minimum wages in 2014 in Turkey, } \\
\text { Belarus, Turkmenistan, Russia, } \\
\text { Azerbaijan, Armenia, Kazakhstan } \\
\text { (USD) }\end{array}$ & $\begin{array}{l}\text { The differences in minimum } \\
\text { wages of Turkey and these } \\
\text { countries (USD) }\end{array}$ & $\%$ \\
\hline Turkey & 497.86 & & \\
\hline Belarus & 156.75 & 341,11 & 68,5 \\
\hline Turkmenistan & 154.37 & 343,49 & 68,9 \\
\hline Russia & 140.37 & 357,49 & 71,8 \\
\hline Azerbaijan & 133.86 & 364 & 73,1 \\
\hline Armenia & 110.41 & 387,45 & 77,8 \\
\hline Kazakhstan & 109.75 & 388,11 & 77,9 \\
\hline
\end{tabular}


The differences between the minimum wages of Belarus, Turkmenistan, Russia, Azerbaijan, Armenia, Kazakhstan and the minimum wage of Turkey are range from 69 to $78 \%$, which may explain, why women from former Soviet Union countries try to find better opportunities in the host country.

The comparison of differences in the minimum wages of Turkey and Ukraine, Georgia, Moldova, Tajikistan, Uzbekistan, and Kyrgyzstan in 2014 is in Table 3.

Table 3 - The differences in minimum wages of Turkey and Ukraine, Georgia, Moldova, Tajikistan, Uzbekistan, Kyrgyzstan in 2014 (times)

\begin{tabular}{|l|l|l|}
\hline Countries & The minimum wages (USD) & $\begin{array}{l}\text { The differences in minimum } \\
\text { wages (times) }\end{array}$ \\
\hline Turkey & 497.8 & \\
\hline Ukraine & 93.98 & 5.3 times \\
\hline Georgia & 65.61 & 7.6 times \\
\hline Moldova & 61.49 & 8.1 times \\
\hline Tajikistan & 50.02 & 9.95 times \\
\hline Uzbekistan & 40.5 & 12.29 times \\
\hline Kyrgyzstan & 15.44 & 32.24 times \\
\hline
\end{tabular}

The minimum wage of Turkey (approximately 497.8 USD per month) in 2014 was 5 to 32 times higher than that of Ukraine, Georgia, Moldova, Tajikistan, Uzbekistan, and Kyrgyzstan in 2014.

We would also like to compare GDP per capita (USD) between Turkey and former Soviet Union countries during the period 2009-2013.

\section{THE GDP PER CAPITA IN TURKEY AND FORMER SOVIET UNION COUNTRIES DURING THE PERIOD 2009-2013}

According to the Conference Board of Canada, income per capita is the most frequently used statistic for comparing economic well-being across countries. It is calculated as gross domestic product (GDP) per capita - it is not a measure of personal income. Therefore, income per capita measures the value of goods and services exchanged in the marketplace. High performance in this category, either in terms of growth or the level of per capita income, does not guarantee a high quality of life. Nevertheless, a country that is not generating enough income for its citizens is hampered in what it can do on the environmental and social fronts [4].

According to Investopedia, a measure of the total output of a country takes the gross domestic product (GDP) and divides it by the number of people in that country. The per capita GDP is especially useful when comparing one country to another because it shows the relative performance of the countries. A rise in per capita GDP signals growth in the economy and tends to translate as an increase in productivity [5].

In Table 4 were compared the GDP per capita in Turkey and former Soviet Union countries during the period 2009-2013 (USD).

Figure 2 was drawn using data from the World Bank [6], and this figure shows differences between the GDP per capita in Turkey and former Soviet Union countries in 2013 (USD) (Fig. 2). The data in Fig. 2 represents the list of former Soviet Union countries and Turkey, ranked by the GDP per capita in 2013:

the GDP per capita in 2013 in Tajikistan was 1,037 USD;

in Kyrgyzstan it was 1,263 USD;

in Uzbekistan it was 1,878 USD;

in Moldova it was 2,239 USD;

in Armenia it was 3,505 USD;

in Georgia it was 3,597 USD;

in Ukraine it was 3,901 USD; 
in Belarus it was 7,576 USD;

in Azerbaijan it was 7,812 USD;

in Turkmenistan it was 7,987 USD;

in Turkey it was 10,972 USD;

in Kazakhstan it was 13,612 USD;

in Russia it was14,612 USD;

in Latvia it was 15,381;

in Lithuania it was 15,530 USD;

in Estonia it was 18,877 USD.

Table 4 - The GDP per capita in Turkey and former Soviet Union countries during 2009-2013

(USD) [6]

\begin{tabular}{|l|l|l|l|l|l|}
\hline Countries & 2009 & 2010 & 2011 & 2012 & 2013 \\
\hline Turkey & 8,626 & 10,136 & 10,605 & 10,661 & 10,972 \\
\hline Armenia & 2,914 & 3,125 & 3,422 & 3,354 & 3,505 \\
\hline Azerbaijan & 4,950 & 5,843 & 7,190 & 7,394 & 7,812 \\
\hline Belarus & 5,176 & 5,819 & 6,306 & 6,722 & 7,576 \\
\hline Estonia & 14,717 & 14,630 & 17,179 & 17,132 & 18,877 \\
\hline Georgia & 2,441 & 2,614 & 3,220 & 3,529 & 3,597 \\
\hline Kazakhstan & 7,165 & 9,071 & 11,358 & 12,120 & 13,612 \\
\hline Kyrgyzstan & 871,2 & 880 & 1,124 & 1,178 & 1,263 \\
\hline Latvia & 12,082 & 11,447 & 13,827 & 13,947 & 15,381 \\
\hline Lithuania & 11,713 & 11,852 & 14,228 & 14,172 & 15,530 \\
\hline Moldova & 1,526 & 1,632 & 1,971 & 2,047 & 2,239 \\
\hline Russia & 8,616 & 10,710 & 13,324 & 14,091 & 14,612 \\
\hline Tajikistan & 669 & 740 & 835 & 953 & 1,037 \\
\hline Turkmenistan & 4,060 & 4,393 & 5,725 & 6,798 & 7,987 \\
\hline Ukraine & 2,545 & 2,974 & 3,576 & 3,874 & 3,901 \\
\hline Uzbekistan & 1,182 & 1,377 & 1,545 & 1,719 & 1,878 \\
\hline
\end{tabular}

\section{OTHER REASONS FOR WOMEN COMING TO TURKEY FROM COUNTRIES OF THE FORMER SOVIET UNION}

We have already explored that the minimum wage and GDP per capita in Turkey is high in comparison with almost all countries of the former Soviet Union. But in addition to economic problems, there are other problems such as wars in Moldova, Armenia, Azerbaijan, Georgia, Ukraine etc., and some women are refugees due to this.

The next reason is the desire to marry. The majority of interviewed women are married, and it seems this was their main reason for coming to Turkey. How did they find their husbands? During tourist tours and seasonal work in Turkey (for example, Antalya); in their countries of origin because there are many Turkish companies in tourism, building, oil and gas areas of economy; by the Internet, friends or acquaintances etc.

But if their desire to marry was achieved, some of them have encountered other kinds of problems that impact on their lives in the host country:

The traditions in their new families and the country in general;

The Muslim religion and traditions are key issues in families;

The traditions of having large families;

The tradition of female unemployment in families;

The necessity of wearing only traditional clothing;

The prohibition of communication with friends or acquaintances;

Sexual, moral and physical violence in families;

Discrimination in families; 
The lack of social insurance, the fear and the uncertainty about their future; Slavery;

Etc.

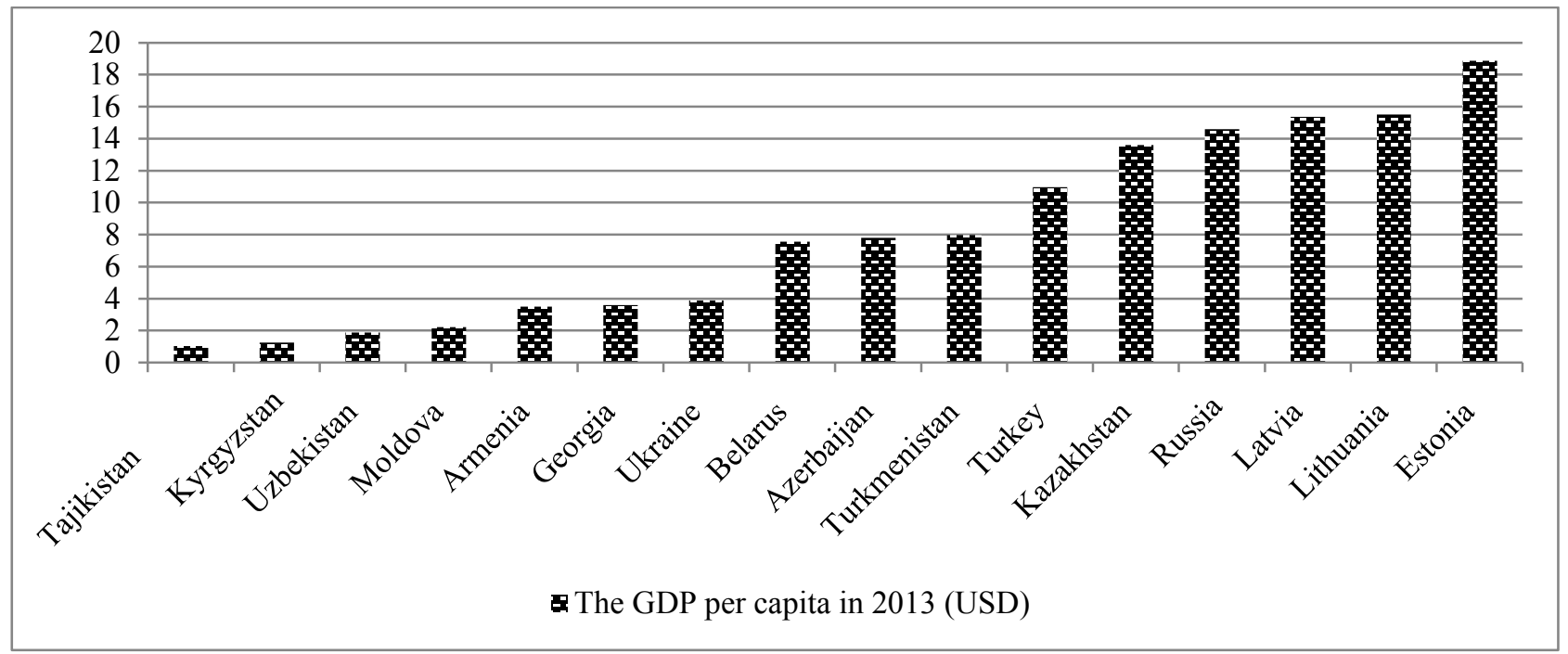

Fig. 2 - The GDP per capita in Turkey and former Soviet Union countries in 2013 (USD)

Of course, between some countries of the former Soviet Union and Turkey there exists International social security agreements, for example, between Turkey and Georgia on Social Security [7] and between the Government of the Republic of Turkey and the Government of Azerbaijan on Social Security [8], but at the same time there are no similar agreements between Turkey and other countries of former Soviet Union. In Turkey it is the Turkish Social Security and Universal Health Insurance Law No.5510 [9], which is also known as the Turkish Social Security Law (the date of enactment of the Law was on May 31, 2006 and the date of entry into force was on October 01, 2008), and because of this Law women - wives of Turkish men have entitlement to social security in the host country. In this case, in particular Article 34 of the Act No.5510, female migrants who are wives or widows of Turkish men and their children can be protected by this Law (Amended on April 17, 2008 - 5754/21st Art.). Therefore these women - wives or widows of Turkish men have entitlement to social insurance or part of the pension of their husbands.

\section{CONCLUSIONS}

Issues in countries of the former Soviet Union, - economic, political crises, wars, unemployment, poverty, low wages and pensions are driving mechanisms that stimulate female migration to Turkey from their countries of origin.

In the framework of our scientific project we held semi-structured interviews and focus-groups with women of different levels of education and culture, and different social statuses according to the status of their husbands in Turkey, but the majority of them are not sure about their future in the host country. According to the results of our investigations, the majority of women from countries of the former Soviet Union came to Turkey with the desire to marry, but after their marriage some of them encountered other problems relating to Turkish traditions and the Muslim Religion. Therefore for some women it is very difficult to adapt and integrate into Turkish society and families. These women need psychological, physical, financial and legal help and support in the host country because the majority of them do not know Laws or even the language of the host country. 


\section{References}

[1] J. J. Sabia, R. B. Nielsen, Minimum Wages, Poverty, and Material Hardship: New Evidence from the SIPP, Review of Economics of the Household (2013).

[2] D. Neumark, W. L. Wascher, Minimum Wages, Cambridge, MA: MIT Press (2008).

[3] Wikipedia: List of minimum wages by country. Information on http://en.wikipedia.org/wiki/List_of_minimum_wages_by_country.

[4] The Conference Board of Canada: Income Per Capita. Information on http://www.conferenceboard.ca/hcp/details/economy/income-per-capita.aspx.

[5] Investopedia: Per Capita GDP. Information on http://www.investopedia.com/terms/p/percapita-gdp.asp.

[6] The World Bank: GDP per capita (current US\$). Information on http://data.worldbank.org/indicator/NY.GDP.PCAP.CD.

[7] Agreement between Turkey and Georgia on Social Security. Done at Izmir on December 11, 1998. Resmi Gazete, 2003-11-12, No. 25287, pp. 57-69 (2003). Information on http://www.ilo.org/dyn/natlex/natlex4.detail?p_lang=en\&p_isn=65891\&p_country=TUR\&p_c ount $=781 \&$ p_classification $=23.01 \& p \_$classcount $=71$

[8] Agreement between the Government of the Republic of Turkey and the Government of Azerbaijan on Social Security. Done at Ankara on July 17, 1998. Resmi Gazete, 2001-01-22, No. 24295, pp. 284-309 (2001). Information on http://www.ilo.org/dyn/natlex/natlex4.detail?p_lang=en\&p_isn=61727\&p_country=TUR\&p_c ount $=781 \&$ p_classification $=23.01 \& p \_$classcount $=71$

[9] Turkish Social Security and Universal Health Insurance Law: 5510. (The date of enactment of the Law was on May 31, 2006 and the date of entry into force was on October 01, 2008). Information on http://turkishlaborlaw.com/turkish-social-security-law-no-5510. 